\title{
Seroprevalence of HIV in pregnant women in tertiary care hospital Kota, India
}

\author{
Suman Bala* \\ Department of Obstetrics and Gynecology, Medical College of Kota, Kota, Rajasthan, India \\ Received: 29 June 2017 \\ Accepted: 25 July 2017 \\ *Correspondence: \\ Dr. Suman Bala, \\ E-mail: drsuman924@gmail.com \\ Copyright: (C) the author(s), publisher and licensee Medip Academy. This is an open-access article distributed under \\ the terms of the Creative Commons Attribution Non-Commercial License, which permits unrestricted non-commercial \\ use, distribution, and reproduction in any medium, provided the original work is properly cited.
}

\begin{abstract}
Background: As HIV infection in women occur primarily during reproductive years hence incidence of HIV infection specially in sexually active women is most sensitive marker to track course of HIV epidemics. It is easy to measure prevalence in pregnant women. This study was done to determine the seroprevalence of HIV in pregnant women in Medical College, Kota, India.

Methods: The study was conducted over the year January2016 to April 2017 and included women either attending ANC or unbooked and referred cases came for delivery.

Results: Only 5 out of 15250 ANC were found positive while total 13 cases were positive including unbooked and referred cases. Majority of women53.84\% were in age group24-29 years and $61.54 \%$ were primigravida and $38.46 \%$ were multigravida. Seroprevalence of HIV infection was only $0.00055 \%$ in my study during 16 months period.

Conclusions: Appropriate antenatal screening, interventions during pregnancy, delivery and breastfeeding will bring down the mother to child transmission of HIV.
\end{abstract}

Keywords: HIV, Pregnant women, Seroprevalence

\section{INTRODUCTION}

Human immunodeficiency virus is a RNA retro virus. HIV infection is most dreadful but preventable. It is usually transmitted three ways: through unprotected sexual intercourse, heterosexual or homosexual; through blood or blood products, donated semen or organs; or from an infected mother to her child (vertical transmission). More than $70 \%$ of infections are a result of heterosexual transmission and over $90 \%$ of infections in children result from mother-to-child transmission.

WHO stated that global HIV prevalence rate was $\sim 35$ million in 2013. Around 3.2 million HIV infected children below 15 years of age. ${ }^{1}$ Women in the developing world are at higher risk of HIV infection than their male counterparts for a number of reasons, biological and sociological.

The rate of transmission of HIV from male to female is two to three higher than that from female to male. ${ }^{2}$ The Langerhans' cells of the cervix may provide a portal of entry for HIV and it has been suggested that some HIV serotypes may have higher affinity for these, and therefore to be more efficient in heterosexual transmission. ${ }^{3}$

Early marriage, violence, sexual abuse and illiteracy are the major socioeconomic reasons of their vulnerability to HIV infection. HIV screening in antenatal women is important because HIV can be transmitted from an infected mother to child during pregnancy, labor, delivery and through breast feeding. It is around $25-48 \%$ 
transmission in developing countries. Upto $20 \%$ of breastfed infant may aquire HIV depending upon duration of breast feeding and other risk factors like breast abscess, mastitis, cracked nipple. ${ }^{4}$

In 1986 the govt of India established National AIDS control committee to formulate a strategy for HIV-AIDS prevalence. India launched a National AIDS control program in 1987.5

Prevention of parent to child transmission(PPTCT) program has been launched in year $2002 .^{6}$

To prevent mother to child transmission in developing countries TLE (Tenofovir, Lamivudine, Efavirenz) administered to mother and Nevirapine to infant till 6wks.

\section{METHODS}

The study was conducted at J K Lone Hospital attached with medical college Kota, Rajasthan, India.

This study was hospital based retrospective study which included total 23673 pregnant women, 15250 from ANC and 8423 women came for delivery either unbooked or referred. Study was conducted duration of 16 months i.e. January 2016 to April 2017. For all women first pretest counseling was done and then informed consent was taken, after it blood sample collected. The sample tested for HIV antibodies as per NACO guidelines. First antibodies test was ELISA, if the initial test is positive then it is confirmed by using two other supplement tests like HIV RNA test and P24 Antigen test, western blot test. ${ }^{7}$ After the confirmation of HIV, in positive patient's posttest counseling done. Results kept private and confidential. The HIV positive women get their CD4 counts and tested for other infections.

For all positive women proper, antenatal care and ART given and advised hospital delivery following universal precautions.

\section{RESULTS}

Data was collected and analyzed from pregnant women who were tested during the period of 16 months from January 2016 to April 2017.

Table 1: Prevalence of HIV infection in pregnant women.

\begin{tabular}{|llll|}
\hline & $\begin{array}{l}\text { ANC/ } \\
\text { booked }\end{array}$ & $\begin{array}{l}\text { Unbooked/ } \\
\text { referred }\end{array}$ & Total \\
\hline No. of patients & 15250 & 8423 & 23673 \\
\hline Positive patients & 5 & 8 & 13 \\
\hline Prevalence \% & 0.00033 & 0.00095 & 0.00055 \\
\hline
\end{tabular}

Total 23673 women were ready for counseling and HIV testing under ICTC. Overall, HIV antibodies were detected in 13 out of 23673 of the subject, thus HIV prevalence rate was $0.00055 \%$ (Table 1 ).

Majority of the HIV positive pregnant women (53.84\%) were in the age group of 25-29 years followed by same in 20-24years $(23.08 \%)$, and $30-34$ years $(23.08 \%)$ (Table 2). Out of 13 HIV positive women, $61.53 \%$ HIV positive women were primigravida and $38.46 \%$ were multigravida.

Table 2: Age wise distribution in pregnant women.

\begin{tabular}{lll} 
Age (years) & No. of women & $\%$ \\
\hline $20-24$ & 7 & 53.84 \\
\hline $25-29$ & 3 & 23.08 \\
\hline $30-34$ & 3 & 23.08 \\
\hline Total & 13 & 100 \\
\hline
\end{tabular}

\section{DISCUSSION}

In present study seroprevalence of HIV infection $0.00055 \%$ noted among 23673 pregnant women. Similarly, studies done by Giri et al and Patil et al at Maharashtra observed the prevalence of HIV as $0.41 \%$ and $0.44 \%$ respectively. ${ }^{8} 9$ While a study by Gupta et al done in North India revealed that the prevalence of HIV was found to be $0.88 \% .{ }^{10}$ A study conducted by Khokar et al at tertiary care Hospital, Gujarat, observed prevalence of HIV as $0.35 \% .{ }^{11}$ Although my results are contrast to prevalence in India i.e. $0.27 \%$ in 2015.

Six Indian states are considered to have high prevalence i.e. Manipur, Nagaland, Andhrapradesh, Tamilnadu, Karnatka and Maharastra. Rajasthan considered as low prevalence state. In Rajasthan decreasing trend of HIV prevalence in pregnant women (Table 3 ) as data collected by SIHFW (Jaipur). ${ }^{12}$ Udaipur, Jhodhpur, Jalore, and Sirohi districts have high incidence of seropositivity in Rajasthan. Kota district comes in very low prevalence area.

Table 3: Year wise prevalence of HIV in pregnant women.

\begin{tabular}{ll} 
Year & Prevalence \% \\
2002 & 0.07 \\
2004 & 0.04 \\
2005 & 0.05 \\
2006 & 0.00 \\
2007 & 0.00 \\
2008 & 0.00 \\
\hline
\end{tabular}

Decrease in prevalence of HIV-AIDS is due increase awareness among society leading to increase in number of pregnant women attending ICTCs. This reflects the importance of trained staff, proper counseling regarding disease, ANC care and institutional delivery. Nowadays knowledge regarding safe sex practices and self-care among students started from teenagers and college level which also shows good impact. 
In the present study, out of those $13 \mathrm{HIV}$ positive pregnant women maximum number of clients tested seropositive ie $53.84 \%$ were in the age group of $25-29$ years, followed by age group 20-24 years $(23.08 \%)$ than older age group. Similar findings are revealed in the study done by Khokar et al and Sarkate et al. ${ }^{11,13}$ This is because of the fact that 25 to 29 years is the most sexually active age group. Young women are more vulnerable to the HIV epidemic and the virus is more easily passed to young women because of their immature vaginal tracts and easily torn tissues; meanwhile, gender inequities in many countries prevent young women from negotiating safer sexual practices including condom use. High prevalence in this group can be considered as forecasting of financial burden as well as loss of youth for the nation (Dash et al). ${ }^{14}$

Among HIV-positive pregnant women in the present study, majority, 8 (61.54\%), were primigravida while 14 $(38.46 \%)$ were multigravida. A study done by Patil et al also revealed that, out of 309 HIV positive pregnant women studied, majority $166 \quad(53.83 \%)$ were primigravida and $143(46.2 \%)$ were multigravida. ${ }^{9}$ These findings are also consistence with study by Verma et al and Dash et al. ${ }^{14,15}$ The percentage of primigravida coming for institutional delivery is significantly more than multigravida, which again suggests the increased awareness of people towards HIV/AIDS. It is observed in present study that $83.33 \%$ clients were housewives and $16.67 \%$ clients were working.

\section{CONCLUSION}

This study concludes that recently prevalence rate of HIV in pregnant women is decreasing. This indicates that prevention campaigns are working effectively. ICTC can provides comprehensive, family centered clinical and supportive services by continuous information, education and counseling that empower the pregnant woman to take her own decisions and prevent the transmission of HIV to her infant.

\section{Funding: No funding sources}

Conflict of interest: None declared

Ethical approval: The study was approved by the Institutional Ethics Committee

\section{REFERENCES}

1. Praveena P, Edward S, Kannan L. A study on cognizance of vertical transmission of HIV/AIDS among pregnant women attending antenatal clinic in a tertiary care hospital, Chennai. Int J Community Med Public Health. 2016;3:408-13.

2. Royce RA, Sena A, Cates W, Cohen M. Sexual transmission of HIV. N Engl J Med. 1997;15:1072-8.

3. Soto-Ramirez LE, Renjifo B, McLane MF, Marlink R, O'hara C, Sutthent R et al. HIV-1 Langerhans' cell tropism associated with heterosexual transmission of HIV. Science. 1996;271:1291-3.

4. NACO Guidelines for the prevention of mother to child transmission of HIV Available at http://www.naco.nic.in/pmtct.html.

5. UNAIDS, AID Epidemic update. December 2004. NACO Annual report 2002-2004. Available at http://files.unaids.org/en/media/unaids/contentassets/ documents/unaidspublication/2004/GAR2004_en.pdf

6. Ashtagi GS, Metgud CS, Walvekar PR, Naik VA. Prevalence of HIV among rural pregnant women attending PPTCT services at KLE Hospital, Belgaum. Al Ameen J Med Sci. 2011;4(1):45-8.

7. National AIDS Control Organization, Ministry of Health and Family Welfare, Government of India. Detection of HIV infection. In: Guidelines on HIV Testing, March 38-53.

8. Giri PA, Bangal VB, Phalke DB. Prevalence of HIV among rural pregnant women attending antenatal clinics at Pravara Rural Hospital, Loni, Maharashtra, India. Int J Health Allied Sci. 2012;1:13-5.

9. Patil VM, Moray AP, Patil SP. Ten years' trend of HIV seroprevalence among Indian pregnant women attending antenatal clinic at tertiary hospital in Dhule, Maharashtra, India. Int J Reprod Contracept Obstet Gynecol. 2017;5(5):1514-9.

10. Gupta S, Gupta R, Singh S. Seroprevalence of HIV in pregnant women in North India: a tertiary care hospital based study. BMC Infect Dis. 2007;7(1):133.

11. Khokhar N, Jethwa D, Lunagaria R, Panchal N. Original research article seroprevalence of hepatitis $\mathrm{b}$, hepatitis c, syphilis and hiv in pregnant women in a tertiary care hospital, Gujarat, India. 2015;4(9):188-94.

12. District level epidemiological profiling of HIV/AIDS using data triangulation, Rajasthan. Report submitted to NACO by SIHFW, Jaipur (SIHFW an ISO:9001:2008 certified institution).

13. Sarkate $P$, Paranjpe $S$, Ingole $N$, Mehta $P$. Monitoring HIV epidemic in pregnant women: are the current measures enough? J Sexually Transmitt Dis. 2015;2015.

14. Dash M, Mohantay I, Sahu S, Narasimham M, Padhi S, Panda P. Declining HIV seroprevalence among pregnant women in South Odisha, India: a six and half year tertiary care hospital based. IJBR. 2012;3(7):546-51.

15. Verma P. Prevalence of HIV among pregnant women attending antenatal clinics at a tertiary care hospital in Central India. Indian J Res. 2002;4(7):59.

Cite this article as: Bala S. Seroprevalence of HIV in pregnant women in tertiary care hospital Kota, India. Int J Reprod Contracept Obstet Gynecol 2017;6:3989-91. 